\title{
A Reliable and Reproducible Model for Assessing the Effect of Different Concentrations of $\alpha$-Solanine on Rat Bone Marrow Mesenchymal Stem Cells
}

\author{
Adriana Ordóñez-Vásquez, ${ }^{1}$ Lorenza Jaramillo-Gómez, ${ }^{2}$ \\ Camilo Duran-Correa, ${ }^{2}$ Erandi Escamilla-García, ${ }^{3}$ \\ Myriam Angélica De la Garza-Ramos, ${ }^{3}$ and Fernando Suárez-Obando ${ }^{1}$ \\ ${ }^{1}$ Instituto de Genética Humana, Facultad de Medicina, Pontificia Universidad Javeriana, Bogotá, Colombia \\ ${ }^{2}$ Centro de Investigaciones Odontológicas, Facultad de Odontología, Pontificia Universidad Javeriana, Bogotá, Colombia \\ ${ }^{3}$ Unidad de Odontología Integral y Especialidades, Centro de Investigación y Desarrollo en Ciencias de la Salud, \\ Facultad de Odontología, Universidad Autónoma de Nuevo León, Mexico \\ Correspondence should be addressed to Fernando Suárez-Obando; fernando.suarez@javeriana.edu.co
}

Received 3 July 2017; Revised 17 September 2017; Accepted 27 September 2017; Published 22 October 2017

Academic Editor: Paolo De Fabritiis

Copyright (C) 2017 Adriana Ordóñez-Vásquez et al. This is an open access article distributed under the Creative Commons Attribution License, which permits unrestricted use, distribution, and reproduction in any medium, provided the original work is properly cited.

\begin{abstract}
Alpha-solanine ( $\alpha$-solanine) is a glycoalkaloid present in potato (Solanum tuberosum). It has been of particular interest because of its toxicity and potential teratogenic effects that include abnormalities of the central nervous system, such as exencephaly, encephalocele, and anophthalmia. Various types of cell culture have been used as experimental models to determine the effect of $\alpha$-solanine on cell physiology. The morphological changes in the mesenchymal stem cell upon exposure to $\alpha$-solanine have not been established. This study aimed to describe a reliable and reproducible model for assessing the structural changes induced by exposure of mouse bone marrow mesenchymal stem cells (MSCs) to different concentrations of $\alpha$-solanine for $24 \mathrm{~h}$. The results demonstrate that nonlethal concentrations of $\alpha$-solanine $(2-6 \mu \mathrm{M})$ changed the morphology of the cells, including an increase in the number of nucleoli, suggesting elevated protein synthesis, and the formation of spicules. In addition, treatment with $\alpha$-solanine reduced the number of adherent cells and the formation of colonies in culture. Immunophenotypic characterization and staining of MSCs are proposed as a reproducible method that allows description of cells exposed to the glycoalkaloid, $\alpha$-solanine.
\end{abstract}

\section{Introduction}

Alpha-solanine ( $\alpha$-solanine) is a glycoalkaloid present in potato (Solanum tuberosum) and fruits, such as apple (Malus domestica), cherry (Prunus avium), eggplant (Solanum melongena), and tomato (Solanum lycopersicum). In 1820, Desfosses characterized this glycoalkaloid [1]; since then it has been discovered that the concentration of $\alpha$-solanine is higher in the stems, leaves, husk, and tubers of potato [2]. The substance has been of interest to researchers because of its toxicity and possible teratogenicity in humans. For example, early reports associated $\alpha$-solanine with the deaths of several children in Great Britain in 1899 and with the poisoning of several individuals in Germany in 1922 [3-5]. Outbreaks of $\alpha$-solanine poisoning were also reported throughout the 20 th century in several countries $[6,7]$. The symptoms of poisoning with this glycoalkaloid (respiratory distress, nausea, vomiting, and diarrhea) are related to the inhibition of acetylcholinesterase [8]; however, the precise mechanism underlying its toxic effects remains under investigation.

Alpha-solanine has been of particular interest because of its toxicity and potential teratogenicity, particularly since 1972 when Renwick, in a controversial hypothesis based on epidemiological investigations, suggested an association between the potato tuber and development of neural tube defects (NTD) [9]. The study demonstrated a significant 
correlation between human populations that consumed large amounts of Solanum tuberosum and the development of NTD [10]. This correlation was of interest in the context of the discovery of the slight mutagenicity of $\alpha$-solanine in vitro, its embryotoxicity in experimental animals $[8,11]$, and teratogenic effects in several mammals [12-14]. Teratogenic effects include abnormalities of the central nervous system, such as exencephaly, encephalocele, and anophthalmia [15]. The association of $\alpha$-solanine with teratogenic effects in animal models is less significant, given that the estimated average consumption of glycoalkaloids derived from potatoes is $12.75 \mathrm{mg} /$ day (around $0.18 \mathrm{mg} / \mathrm{kg}$ body weight). This value is close to one-fifth of the dose that has shown toxicity in humans ( $1 \mathrm{mg} / \mathrm{kg}$ body weight) [8]; however, as $\alpha$-solanine is insoluble, its toxic effects may stem from its capacity to accumulate in the body for up to $24 \mathrm{~h}$ after ingestion. Moreover, the specific effects of $\alpha$-solanine on human physiology and cell proliferation remain poorly understood [2]. Hence, the long-term effects and tissue accumulation of this glycoalkaloid are aspects of concern.

Various types of cell culture have been used as experimental models to determine the effect of $\alpha$-solanine on cell physiology. For example, studies of toxicity have been performed using human red blood cells [16], embryonic Xenopus cells [17], mouse cardiac cells [18], cancer cell lines, fibroblasts [19, 20], and epithelial cells [21]. In many of these studies, cells have been exposed to concentrations of $\alpha$-solanine ranging from 3 to $60 \mu \mathrm{M}$. A concentration of $18.5 \mu \mathrm{M}$ was nontoxic to human melanoma cells but cytotoxic in fibroblasts [20], concentrations up to $60 \mu \mathrm{M}$ exhibited low cytotoxicity in rat glioma cells [22], and concentrations up to $50 \mu \mathrm{M}$ altered the integrity of the epithelial barrier and membrane permeability and inhibited proliferation of epithelial cells [21]. Similar effects have been described in breast cancer and liver cancer cell lines [19]. The observed changes in cultured cells are a consequence of the action of $\alpha$-solanine in the cell membrane lipid bilayer [23]. In addition to inhibiting acetylcholine esterase [24], $\alpha$-solanine interferes substantially with the structure and function of the cell membrane $[24,25]$. Although the exact mechanism by which $\alpha$-solanine induces changes in membrane barrier function remains unclear [26], the damage observed induces the exit of ions and proteins from mammalian cells [27].

Recently, the relevance of $\alpha$-solanine has increased because of its possible role as an inhibitor of breast, pancreatic, and esophageal cancers and melanoma [19, 20, 28, 29]. The results of these studies suggest the importance of analysis of morphological and structural changes, such as chromatin condensation and the presence of intracytoplasmic vacuoles, in cells exposed to $\alpha$-solanine, along with phenotypic alterations, such as its effect on cell culture expansion, and the morphology and physiology of stem cells [30-32].

The morphological changes in the mesenchymal stem cell upon exposure to $\alpha$-solanine have not been established. In this context, the possible link between $\alpha$-solanine and teratogenicity (toxicity to undifferentiated cells, such as embryonic cells) and the associated complex phenotypic manifestations, such as NTD, are of interest. Given the lack of knowledge of the precise mechanisms of action of $\alpha$-solanine and the fact that teratogenic effects of this compound in humans have not been ruled out, it is imperative to develop protocols to determine its detailed mechanisms of action at nontoxic concentrations in nondifferentiated, living, adherent cells. This study aimed to describe the structural changes induced by exposure of mouse bone marrow mesenchymal stem cells (MSCs) to different concentrations of $\alpha$-solanine for $24 \mathrm{~h}$.

\section{Materials and Methods}

Bone marrow stem cells were obtained from four healthy Lewis strain rats (LEW/SsNHsd). Lewis rats were selected because these animals have a low prevalence of spontaneous neural tube defects (less than $1: 1000$ ) [33]. None of the donor rats received previous treatment.

2.1. Bone Marrow Extraction and Cell Culture. The Lewis rats were euthanized with $\mathrm{CO}_{2}$. Immediately afterward, the skin, muscle tissue, and periosteum were dissected from the femur and tibia to expose the bones, which were separated from each limb, stored in saline solution, and transferred immediately from the animal facility to the laboratory for processing. Using surgical instruments, in a laminar flow cabinet (Labconco, Logic, Class II Type A2) the epiphyses of the bones were broken, loaded with $2 \mathrm{ml}$ of base medium (see Preparation of Cultures and Exposure to $\alpha$-Solanine, below) using a syringe, and their interiors flushed. The eluted volume was collected in 15-ml Eppendorf conical tubes and centrifuged (Thermo Scientific, Heraeus Biofuge Primo R) at $650 \times \mathrm{g}$ for $5 \mathrm{~min}$ at $4^{\circ} \mathrm{C}$. The supernatant was discarded, the pellet was resuspended in $1 \mathrm{ml}$ of base medium, and the total number of cells per $\mathrm{ml}$ was determined. Cell counting was performed using the trypan blue exclusion test for cell viability, with $0.4 \%$ trypan blue (Sigma, T-8154) in a Neubauer chamber. Cells were seeded in Corning ${ }^{\circledR}$ cell culture flasks with $25 \mathrm{~cm}^{2}$ surface area (Corning, CLS430168) at a concentration of $5 \times 10^{5}$ cells per flask and maintained at $37^{\circ} \mathrm{C}$ with $5 \% \mathrm{CO}_{2}$ in an incubator (Thermo Scientific, Series $8000 \mathrm{WJ}$ ). Culture medium was replaced every three days until the cells reached $90 \%$ confluence; this procedure established the primary culture (PC0).

2.2. Purification of $\mathrm{CD}^{+} 5^{+}$Cells and Population Subculture. PC0 cells were detached using $0.25 \%$ trypsin and $0.02 \%$ EDTA solution (Sigma, T-4049) to form a cell suspension. Cells were then collected by centrifugation at $650 \times \mathrm{g}$ for $5 \mathrm{~min}$ at $4^{\circ} \mathrm{C}$. The cells were counted, and the $\mathrm{CD} 45^{+}$fraction was separated by incubation with an anti-CD45 antibody (BD Biosciences, 554878) for $15 \mathrm{~min}$ at $4^{\circ} \mathrm{C}$, using $10 \mu \mathrm{l}$ of antiCD45 antibody per $1 \times 10^{6}$ cells, washed with a 1:20 solution of MACS BSA Stock Solution (MACS Miltenyi Biotec, 130048-701) in MACS Buffer (AutoMACS ${ }^{\mathrm{TM}}, 130-091-22$ ), then incubated with a secondary Anti-FITC antibody Microbeads (MACS Miltenyi Biotec, 130-048-701) coupled to magnetic beads (Miltenyi Biotech, Germany) for $15 \mathrm{~min}$ at $4^{\circ} \mathrm{C}$. The suspension was applied to a magnetic separation column (Miltenyi Biotec, LS-MACS Columns), the labeled cells bound to the column, the unlabeled cell fraction, containing the $\mathrm{CD} 45^{-}$cell fraction, was eluted and subcultured in base 
medium, representing the first passage (P1). When $\mathrm{P} 1$ cells reached $90 \%$ confluency, they were disaggregated, collected by centrifugation, counted, and successively subcultured until they reached the third passage (P3), and then they were used for experiments.

2.3. Characterization of Cultured Cells. The immunophenotypic characteristics of the cell cultures at P3 were determined by flow cytometry [34], using specific antibodies coupled with fluorochromes PE, APC, and FITC as follows: CD45-PE (554878, DB Biosciences), CD29-Biot/Strep-APC (555004, DB Biosciences), CD90-FITC (130-094-527, Miltenyi Biotec), CD71 = PE (554891, BD Biosciences), and CD106-PE (559229, BD Biosciences). Cells experimentally exposed to $\alpha$-solanine expressed high levels of the CD90, CD29, CD71, and CD106 stem cell markers. The undifferentiated status of the cells was verified by inducing them to differentiate into an osteogenic lineage, according to standardized laboratory procedures (unpublished results).

2.4. Preparation of Cultures and Exposure to $\alpha$-Solanine. The $\alpha$-solanine glycoalkaloid $\left(\mathrm{C}_{45} \mathrm{H}_{73} \mathrm{NO}_{15}\right.$, solatunin; $\alpha$-solanine), a trisaccharide consisting of glucose, galactose, rhamnose, and a solanidine aglycone ring (purity > 95\%, Santa Cruz Biotechnology SC-252340), was used. Alpha-solanine was solubilized with $0.45 \% \mathrm{NaCl}$ (Sigma-Aldrich S7653), $0.25 \%$ acetic acid $\left(\mathrm{CH}_{3} \mathrm{COOH}\right.$, Sigma-Aldrich A9967), and $0.2 \%$ dimethyl sulfoxide (Sigma-Aldrich, D2650). MSCs exposed to $\alpha$-solanine were cultured in Corning cell culture flasks, with $25 \mathrm{~cm}^{2}$ surface area (Corning CLS430168), in $\alpha$ MEM culture medium (Gibco 12000-014). The medium was supplemented with $10 \%$ of fetal bovine serum (Gibco 16000044), 1\% penicillin and streptomycin (Gibco 15240-062), an antimycotic (amphotericin B), 1\% GlutaMAX-I (Gibco $35050-061)$, and $2.2 \mathrm{~g}$ sodium bicarbonate $\left(\mathrm{NaHCO}_{3}\right.$, Merck 106329). This $\alpha$-MEM medium was considered base medium for cell culture.

When rat MSC P3 cultures, reached 95\% confluence, they were separated into 4 cell culture flasks, marking four of them as experimental groups $(\mathrm{A}, \mathrm{B}, \mathrm{C}$, and $\mathrm{D})$; the repeated experiments were labeled $\left(\mathrm{A}^{*}, \mathrm{~B}^{*}, \mathrm{C}^{*}\right.$, and $\left.\mathrm{D}^{*}\right)$, and the flasks were subjected to the following treatments: $A, A^{*}$ : no exposure to the glycoalkaloid (negative control); $\mathrm{B}, \mathrm{B}^{*}$ : exposure to $2 \mu \mathrm{M}$ of $\alpha$-solanine; $\mathrm{C}, \mathrm{C}^{*}$ : exposure to $4 \mu \mathrm{M}$ of $\alpha$ solanine; and D, $\mathrm{D}^{*}$ : exposure to $6 \mu \mathrm{M}$ of $\alpha$-solanine. Human fibroblasts exposed to $\alpha$-solanine $(18.5 \mu \mathrm{M})$ for $24 \mathrm{~h}$ [20] were used as positive controls for cytotoxic characterization. Cells were exposed to $\alpha$-solanine at the indicated concentrations for $24 \mathrm{~h}$ at $37^{\circ} \mathrm{C}$ and $5 \% \mathrm{CO}_{2}$. After treatment, 100 cells were manually counted using inverted microscopy (60x) and a mechanical counter. The number of adhered and nonadherent cells and their phenotypic characteristics were recorded for each of the exposed cultures.

2.5. Cell Culture Staining. Cells from each experimental group (A, B, C, and D) were washed with phosphatebuffered saline, pH 7.4 (Sigma P3813), and stained directly in culture with $30 \mu \mathrm{l}$ of Chinese ink (Pelikan \#17 Schwarz Black) (ref. 70306 4340503), following the protocol of Ordóñez
Vásquez et al. [35]. After staining the cells, their qualitative (morphological description) and quantitative characteristics, including the number of adhered and nonadhered cells, were assessed by optical microscopy. Among adherent cells, the number of cell colonies and the number of cells forming the colonies were determined. Experiments were performed in duplicate.

2.6. Statistical Analysis. To evaluate the significance of differences between the proportions of adhered cells in the treatment groups, a multiproportion comparison test (Marascuilo procedure) with Monte Carlo simulation was used $(\alpha=0.05)$. For comparisons of the numbers of cell colonies and the number of cells in each colony among treatment groups, the Kruskal-Wallis test was used ( $\alpha=0.05)$.

\section{Results}

3.1. Structural Changes in MSCs Exposed to $\alpha$-Solanine. Stem cells are typically small, long, and narrow, containing a large round nucleus surrounded by fine chromatin particles that delimit within it one or two rounds and prominent nucleoli. Fibroblastoid cells are classically heterogeneous in appearance and can be elongated or pyramidal, with an even cytoplasmic to nucleus ratio (Figure 1(a)). Figures 1(b)-1(d) show the morphological changes observed in living rat MSCs exposed to $\alpha$-solanine at three nonlethal concentrations for $24 \mathrm{~h}$.

Structural changes first became evident after exposure to $2 \mu \mathrm{M} \alpha$-solanine and were directly proportional to the concentration used. On treatment with $2 \mu \mathrm{M} \alpha$-solanine, the nucleus remained slightly elongated and became less heterogeneous, with increased perinuclear cytoplasmic density (Figure 1(b)). Cells exposed to $4 \mu \mathrm{M}$ of $\alpha$-solanine lost their characteristic morphology, and the nuclei become less compact and larger, presumably reflecting increased protein synthesis. Cells treated with $\alpha$-solanine exhibited signs of distress, including changes in volume, increased cytoplasmic condensation, changes in the proportion of cells occupied by nuclei, and development of elongated spicules (Figure 1(c)). Although no significant changes in cell size are observed at $2 \mu \mathrm{M}$ and $4 \mu \mathrm{M}$ exposition, there is a significant decrease in cytoplasmic volume in cells exposed to $6 \mu \mathrm{M}$ of $\alpha$-solanine, presumably secondary to condensation and progressive cytoplasmic retraction. Small cells, condensed chromatin, with many short spicules, and white spaces that show cytoplasmic vacuoles and cell isolation are all evident; these morphological changes suggest an early apoptosis process. (Figure $1(\mathrm{~d})$ )

In groups exposed to higher concentrations of $\alpha$-solanine, we observed differences in the shape of nucleoli. There were no differences in the cell morphology between the control group and the MSC group exposed to $2 \mu \mathrm{M} \alpha$-solanine; cells contained 1-3 rounded, distinct, and dark nucleoli (Figure 2(E)).

In contrast, MSC cultures exposed to $4 \mu \mathrm{M}$ of $\alpha$-solanine contained cells with 3-6 nucleoli, all of which were irregular and very small (Figure $2(\mathrm{~F})$ ). In MSCs exposed to $6 \mu \mathrm{M} \alpha$ solanine, no nucleoli-like structures were identified. Characterization of cytoplasmatic extensions/gripping spicules 


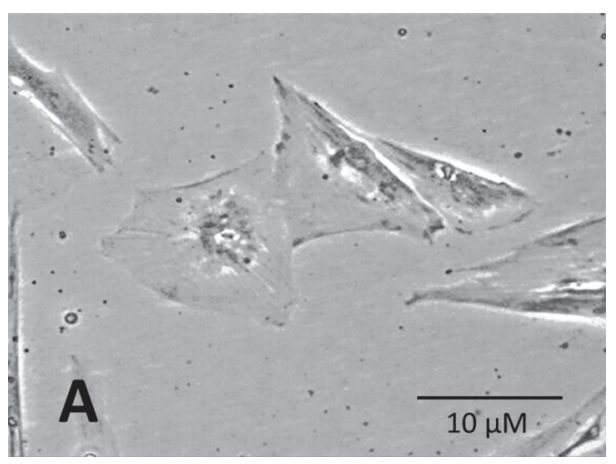

(a)

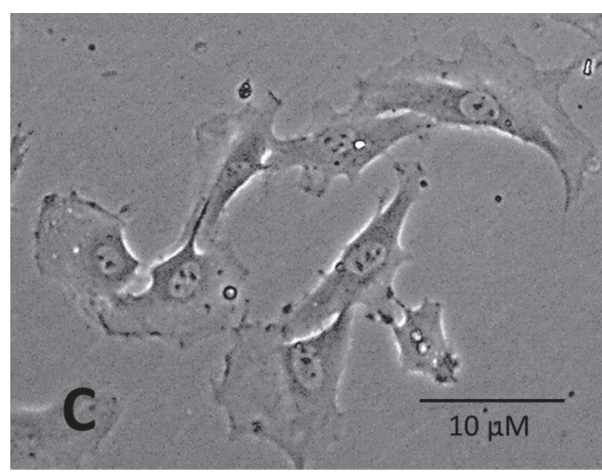

(c)

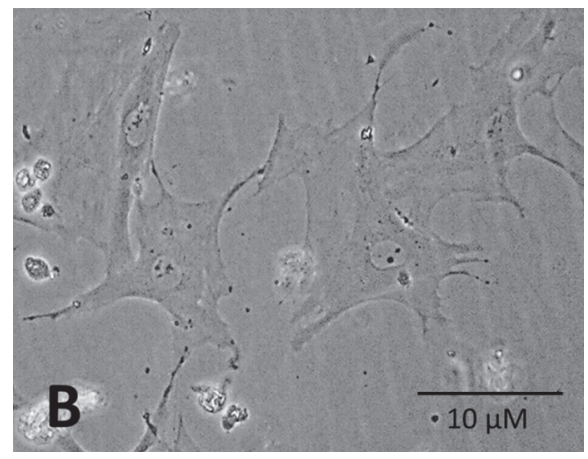

(b)

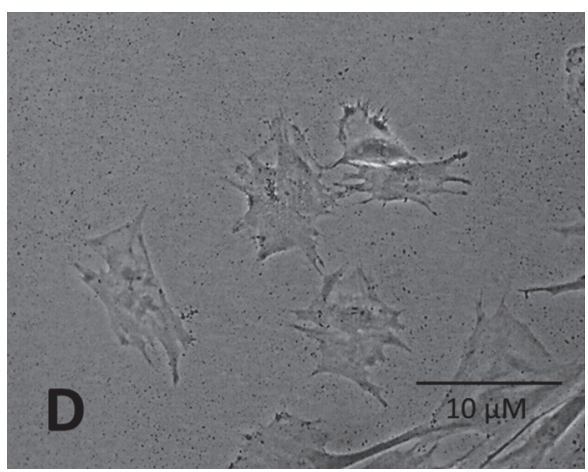

(d)

FIGURE 1: Bone marrow mesenchymal stem cells in culture stained with China ink after 24 hours' exposure to $\alpha$-solanine. (a) No exposure to the glycoalkaloid (negative control); (b) exposure to $2 \mu \mathrm{M}$ of $\alpha$-solanine; (c) exposure to $4 \mu \mathrm{M}$ of $\alpha$-solanine; and (d) exposure to $6 \mu \mathrm{M}$ of $\alpha$-solanine.
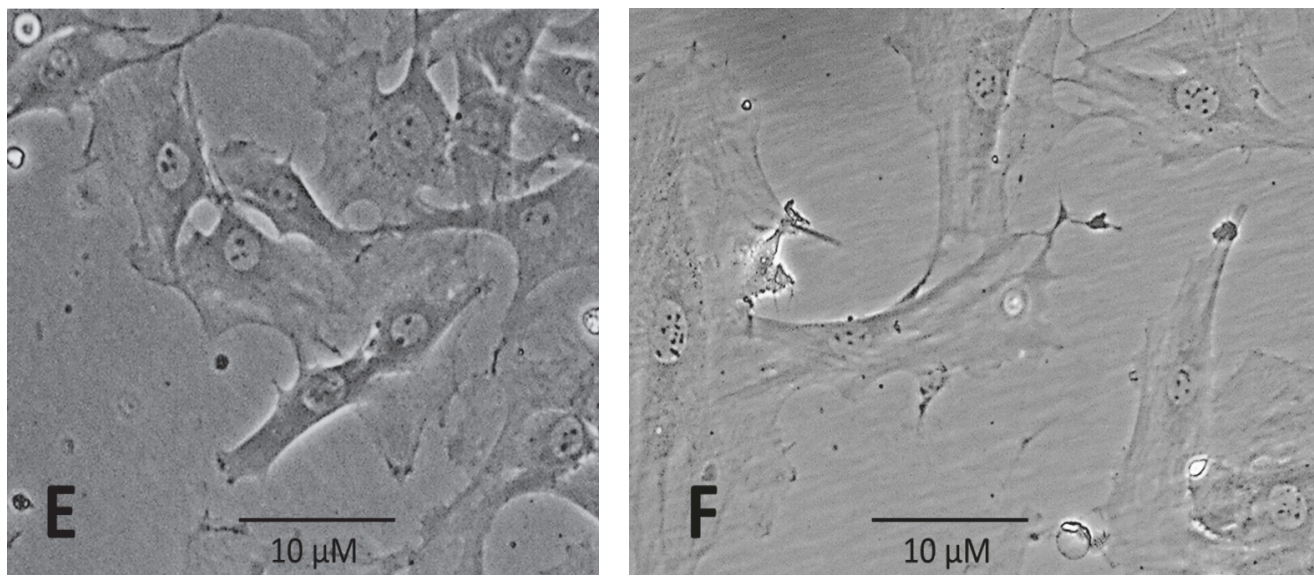

Figure 2: Nucleoli images of bone marrow mesenchymal stem cells in culture stained with China ink after 24 hours' exposure to $\alpha$-solanine. (E) Exposure to $2 \mu \mathrm{M}$ of $\alpha$-solanine, 1 to 3 regular nucleoli. (F) Exposure to $4 \mu \mathrm{M}$ of $\alpha$-solanine, 5 to 7 irregular nucleoli.

indicated that they appeared to respond directly to increasing $\alpha$-solanine concentration. The number of extensions per cell increased proportionally to glycoalkaloid concentration.

\subsection{Cell Adhesion at Different Concentrations of $\alpha$-Solanine.} Quantification of the total number of adherent cells indicated significant differences among the treatment groups (Figure 3). As the concentration of $\alpha$-solanine increased, the number of adherent cells decreased, reaching zero at the maximum treatment concentration $(p<0.0001)$ (see supplementary material regarding the Marascuilo procedure and repeated experiment results, available online at https://doi.org/10.1155/2017/2170306).

\subsection{Influence of $\alpha$-Solanine Concentration on Cell Colony} Formation. At higher concentrations of $\alpha$-solanine, the number of cell colonies decreased (Kruskal-Wallis test, $X^{2}=$ 12.352, $p=0.0061)$. Moreover, as the concentration increased, the number of cells per colony decreased (KruskalWallis test, $X^{2}=21.5, p=0.0001$ ) (Table 1). 
TABLE 1: Differences in the number of cells per colony. As the concentration of $\alpha$-solanine increases the number of adherent's cells and the number of colonies decrease. Cell counting is based on 100 cells. (See supplementary material regarding repeated experiment results.)

\begin{tabular}{lccc}
\hline $\begin{array}{l}\text { Concentrations } \\
\text { of } \alpha \text {-solanine }\end{array}$ & $\%$ adherent cells & $\begin{array}{c}\text { Number of } \\
\text { colonies }\end{array}$ & $\begin{array}{c}\text { Cells per colony } \\
\text { (average) }\end{array}$ \\
\hline $0 \mu \mathrm{M}$ & $97 \%$ & 16 & 5.3 \\
$2 \mu \mathrm{M}$ & $39 \%$ & 10 & 4 \\
$4 \mu \mathrm{M}$ & $30 \%$ & 10 & 2.7 \\
$6 \mu \mathrm{M}$ & $0 \%$ & 0 & 0 \\
\hline
\end{tabular}

Cell adhesion at different

concentrations of $\alpha$-solanine

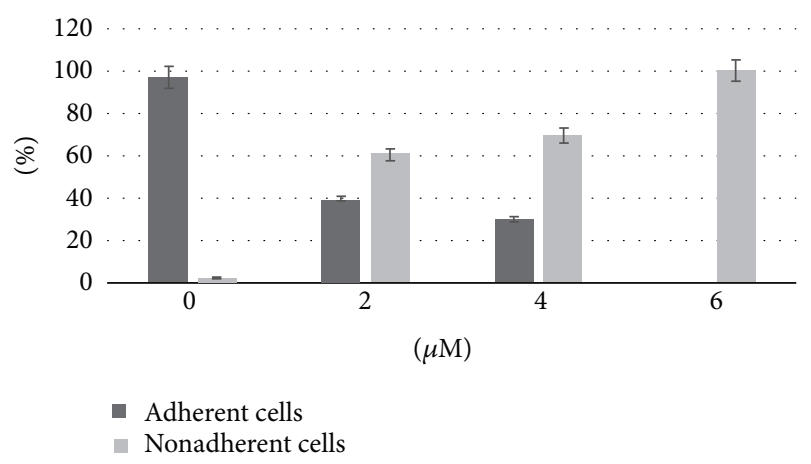

FIGURE 3: Change of adherent and nonadherent cells proportion as the $\alpha$-solanine concentration increases. The repeated experiments showed the same results (see supplementary data).

\section{Discussion}

Qualitative morphological analysis of MSCs exposed to different concentrations of $\alpha$-solanine was performed, demonstrating dose-dependent phenotypic changes, in cell shape, size, development of cytoplasmic extensions, and adhesion. Under control conditions, MSCs dispersed in culture are small, well-defined cells with large round nuclei, prominent nucleoli, and an adjacent extracellular matrix formed by reticular fibrils [36]. The changes in size, shape, and number of nucleoli observed in this study were associated with structural changes secondary to the accumulation of $\alpha$-solanine in the cytoplasm and within intracellular vacuoles, leading to inhibition of cholinesterases and sodium-potassium ATPase pumps [22]. The observed changes in MSC shape were consistent with previous reports of cellular responses to this glycoalkaloid; for example, exposure of toad embryonic cells to $\alpha$-solanine led to alteration of membrane potential, generating both damage to lipid membrane structure and modification of ion transport channels [37, 38].

The observed changes in cell adhesion, indicating a reduced capacity of cells to adhere to the culture flask surface, as well as reduced cell colony formation, confirm that the membrane is the first structure to be affected by $\alpha$-solanine treatment [3] and indicate processes typically observed in cells exposed to metabolic or therapeutic stress [39]. In addition to inhibition of acetylcholine esterase [4], a protein containing a domain associated with cell adhesion [5], $\alpha$ solanine also significantly interferes with the structure and function of the cell membrane $[4,6]$. Progressive damage and destabilization of the mammalian cell membrane can cause cellular contents to escape [7], although the mechanisms underlying the $\alpha$-solanine-induced changes in the barrier function of the membrane remain unclear [8].

Extensions or elongations of reticular fibrils were evident after exposure to $\alpha$-solanine, leading to the formation of spicules. These changes are presumably related to the move towards increased adherence and a consequence of cell responses to paracrine signals, a mechanism responsible for induction of tissue repair in various types of mesenchymal cells within their morphogenetic repertoire of cell differentiation [40].

In contrast to our findings, $\alpha$-solanine had an inhibitory effect on the growth of fibroblasts, arresting them in the G2 phase of the cell cycle [38]. A similar effect was described in HepG2 cells, where, during incremental exposure to $\alpha$ solanine to determine IC50 (half-maximal inhibitory concentration), the proportion of cells in $S$ phase increased, leading to a greater sensitivity of cells in G2 phase to the toxicity of this substance [41], an effect probably mediated by the Bcl-2 family of proteins which regulate apoptosis [42]. Also, the changes in the morphology of the cells may also be mediated by other mechanisms, such as suppression of the Akt/mTOR pathway and induction of autophagy [43], since both pathways have been implicated in the inhibitory activity of $\alpha$-solanine towards tumor cells [29, 44].

Differences were also observed in the size and number of nucleoli per cell. Under normal conditions, cells have one or two distinct compact nucleoli; however, this number increases in cells requiring increased protein synthesis. Moreover, the nucleolus has roles in other cell functions, such as cell cycle regulation, stress responses, telomerase activity, and aging, and changes to this structure indicate alterations in the functional state of the cell. The results of the present study demonstrate that treatment with higher concentrations of $\alpha$-solanine resulted in an increase in the number of nucleoli. This result is as expected, since treatment with this substance causes increased cellular stress, generating elevated protein synthesis and, therefore, a higher number of nucleoli, which have a primary function of ribosome synthesis. These changes could also be the result of the phenomenon of nuclear segregation, which is induced by various substances of vegetable origin and produces similar characteristics and effects to those observed on treatment with $\alpha$-solanine [45].

This study found a marked difference in the percentage of adherent cells between the control group and cells exposed to 2 and $6 \mu \mathrm{M}$ of $\alpha$-solanine; however, no such difference was observed between treatments with 2 and $4 \mu \mathrm{M}$ or 4 to $6 \mu \mathrm{M} \alpha$-solanine. These results may be attributable to a saturation effect, where the maximum influence on cell adhesion capacity was reached at a particular $\alpha$-solanine treatment concentration, after which cell death was triggered.

Overall, our results demonstrate that $\alpha$-solanine produces structural changes in MSCs in a dose-dependent manner, consistent with findings in other cell types, such as cardiac, colon (HT29, T84), and liver (HepG2) cells [18, 21, 46]. 
This study of the morphological parameters of live MSCs in adherent culture describes a simple and reproducible way to qualitatively evaluate the toxicity of glycoalkaloid treatment of multipotential cells. The study demonstrates the importance of basic qualitative observation in the understanding of biological responses of individual cells exposed to stimuli, such as glycoalkaloids [47].

\section{Conclusions}

Immunophenotypic characterization and staining of MSCs are proposed as reliable and reproducible methods that allow description of cells exposed to the glycoalkaloid, $\alpha$-solanine. The method presented permits analysis of parameters including spicule formation, cytoplasmic condensation, the number and characteristics of nucleoli, and cell adhesion characteristics. This study highlights the importance of observations of individual cells and changes to them. The glycoalkaloid, $\alpha$-solanine, has dose-dependent toxic effects, modifying the shape of cells, decreasing their size, increasing the number of nucleoli per cell, causing detachment of adherent cells, and decreasing intercellular adhesion. Although the study is novel, it has limitations, since it is a phenotypic description of cells in culture, which is compatible with previous studies. However, the biological basis of these changes is yet to be described. These imply future studies in relation to the analysis of apoptosis pathways in mesenchymal stem cells [41] and regulation of genes that have been related to NTD as SHROOM3 and can be sensitive to the action of glycoalkaloids during critic periods of embryogenesis [48, 49] and the study of structural changes of the cytoskeleton induced by different concentrations of $\alpha$-solanine [50].

\section{Conflicts of Interest}

The authors declare that they have no conflicts of interest.

\section{Acknowledgments}

The authors would like to thank Editage (https://www.editage .com) for English language editing.

\section{References}

[1] H. W. Conner, "Effect of light on solanine synthesis in the potato tuber," Plant Physiology, vol. 12, no. 1, pp. 79-98, 1937.

[2] D. G. Omayio, G. O. Abong, and M. W. Okoth, "A review of occurrence of glycoalkaloids in potato and potato products," Current Research in Nutrition and Food Science, vol. 4, no. 3, pp. 195-202, 2016.

[3] A. A. Hansen, "Two fatal cases of potato poisoning," Science, vol. 61, no. 1578 , pp. 340-341, 1925.

[4] F. W. Harris and T. Cockburn, "Alleged poisoning by potatoes," Analyst, vol. 43, no. 505, pp. 133-137, 1918.

[5] M. D. Krasowski, D. S. McGehee, and J. Moss, "Natural inhibitors of cholinesterases: implications for adverse drug reactions," Canadian Journal of Anesthesia, vol. 44, no. 5, pp. 525-534, 1997.
[6] R. F. Alexander, G. B. Forbes, and E. S. Hawkins, "A Fatal Case of Solanine Poisoning," British Medical Journal, vol. 2, no. 4575, article 518, 1948.

[7] S. G. Willimott, "An investigation of solanine poisoning," Analyst, vol. 58, no. 689, pp. 431-439, 1933.

[8] L. C. Dolan, R. A. Matulka, and G. A. Burdock, "Naturally occurring food toxins," Toxins, vol. 2, no. 9, pp. 2289-2332, 2010.

[9] A. O. Vásquez and F. Suarez-Obando, "Neural tube defects and folic acid: A historical overview of a highly successful preventive intervention," Historia, Ciencias, Saude - Manguinhos, vol. 22, no. 4, pp. 1115-1172, 2015.

[10] J. H. Renwick, "Hypothesis: anencephaly and spina bifida are usually preventable by avoidance of a specific but unidentified substance present in certain potato tubers," British Journal of Preventive \& Social Medicine, vol. 26, no. 2, pp. 67-88, 1972.

[11] I. Gal, "Possible mechanisms of human teratogenesis by imperfect potato," Human Genetics, vol. 314, no. 3-4, pp. 1968-1971, 1973.

[12] M. Friedman, P. R. Henika, and B. E. Mackey, "Feeding of potato, tomato and eggplant alkaloids affects food consumption and body and liver weights in mice," Journal of Nutrition, vol. 126, no. 4, pp. 989-999, 1996.

[13] Y. I. Korpan, E. A. Nazarenko, I. V. Skryshevskaya, C. Martelet, N. Jaffrezic-Renault, and A. V. El'skaya, "Potato glycoalkaloids: True safety or false sense of security?" Trends in Biotechnology, vol. 22, no. 3, pp. 147-151, 2004.

[14] M. A. Rothschild, M. Oratz, J. Mongelli, and S. S. Schreiber, "Effects of a short-term fast on albumin synthesis studied in vivo, in the perfused liver, and on amino acid incorporation by hepatic microsomes." The Journal of Clinical Investigation, vol. 47, no. 12, pp. 2591-2599, 1968.

[15] W. Gaffield and R. F. Keeler, "Induction of terata in hamsters by solanidane alkaloids derived from Solanum tuberosum," Chemical Research in Toxicology, vol. 9, no. 2, pp. 426-433, 1996.

[16] M. Manrique-Moreno, J. Londoño-Londoño, M. JemiołaRzemińska et al., "Structural effects of the Solanum steroids solasodine, diosgenin and solanine on human erythrocytes and molecular models of eukaryotic membranes," Biochimica et Biophysica Acta (BBA) - Biomembranes, vol. 1838, no. 1, pp. 266277, 2014

[17] M. Friedman, J. R. Rayburn, and J. A. Bantle, "Developmental toxicology of potato alkaloids in the frog embryo teratogenesis assay-Xenopus (FETAX)," Food and Chemical Toxicology, vol. 29 , no. 8, pp. 537-547, 1991.

[18] W. W. A. Bergers and G. M. Alink, "Toxic effect of the glycoalkaloids solanine and tomatine on cultured neonatal rat heart cells," Toxicology Letters, vol. 6, no. 1, pp. 29-32, 1980.

[19] M. Mohsenikia, A. M. Alizadeh, S. Khodayari et al., "The protective and therapeutic effects of alpha-solanine on mice breast cancer," European Journal of Pharmacology, vol. 718, no. 1-3, pp. 1-9, 2013.

[20] M. Lu, Y. Shih, T. Chang Chien, L. Fang, H. Huang, and P. Chen, " $\alpha$-solanine inhibits human melanoma cell migration and invasion by reducing matrix metalloproteinase-2/9 activities," Biological \& Pharmaceutical Bulletin, vol. 33, no. 10, pp. 16851691, 2010.

[21] B. Patel, R. Schutte, P. Sporns, J. Doyle, L. Jewel, and R. N. Fedorak, "Potato glycoalkaloids adversely affect intestinal permeability and aggravate inflammatory bowel disease," Inflammatory Bowel Diseases, vol. 8, no. 5, pp. 340-346, 2002. 
[22] S. Yamashoji and T. Matsuda, "Synergistic cytotoxicity induced by $\alpha$-solanine and $\alpha$-chaconine," Food Chemistry, vol. 141, no. 2, pp. 669-674, 2013.

[23] E. A. J. Keukens, T. de Vrije, C. van den Boom et al., "Molecular basis of glycoalkaloid induced membrane disruption," Biochimica et Biophysica Acta (BBA) - Biomembranes, vol. 1240, no. 2, pp. 216-228, 1995.

[24] D. B. Smith, J. G. Roddick, and J. L. Jones, "Potato glycoalkaloids: Some unanswered questions," Trends in Food Science \& Technology, vol. 7, no. 4, pp. 126-131, 1996.

[25] J. M. Gee, G. M. Wortley, I. T. Johnson et al., "Effects of saponins and glycoalkaloids on the permeability and viability of mammalian intestinal cells and on the integrity of tissue preparations in vitro," Toxicology in Vitro, vol. 10, no. 2, pp. 117128, 1996.

[26] E. A. J. Keukens, T. De Vrije, L. A. M. Jansen et al., "Glycoalkaloids selectively permeabilize cholesterol containing biomembranes," Biochimica et Biophysica Acta (BBA) - Biomembranes, vol. 1279, no. 2, pp. 243-250, 1996.

[27] M. Toyoda, W. D. Rausch, K. Inoue et al., "Comparison of solanaceous glycoalkaloids-evoked $\mathrm{Ca} 2+$ influx in different types of cultured cells," Toxicology in Vitro, vol. 5, no. 4, pp. 347351, 1991.

[28] C. Lv, H. Kong, G. Dong et al., "Antitumor efficacy of a-solanine against pancreatic cancer pancreatic cancer in vitro and in vivo," PLoS ONE, vol. 9, no. 2, article e87868, 2014.

[29] L. Wang, Q.-Q. Sun, S.-J. Zhang et al., "Inhibitory effect of $\alpha$ solanine on esophageal carcinoma in vitro," Experimental and Therapeutic Medicine, vol. 12, no. 3, pp. 1525-1530, 2016.

[30] L. Danisovič, I. Varga, Š. Polák, B. Bajčiková, M. Adamkov, and J. Vojtaššák, "Biological and morphological characterization of in vitro expanded human muscle-derived stem cells," Tsitologiya, vol. 53, no. 6, pp. 482-487, 2011.

[31] M. K. Majumdar, M. A. Thiede, J. D. Mosca, M. Moorman, and S. L. Gerson, "Phenotypic and functional comparison of cultures of marrow-derived mesenchymal stem cells (MSCs) and stromal cells," Journal of Cellular Physiology, vol. 176, no. 1, pp. 57-66, 1998.

[32] Z. Miao, J. Jin, L. Chen et al., "Isolation of mesenchymal stem cells from human placenta: comparison with human bone marrow mesenchymal stem cells," Cell Biology International, vol. 30, no. 9, pp. 681-687, 2006.

[33] D. E. Poswillo, D. Sopher, and S. Mitchell, "Experimental induction of foetal malformation with "blighted" potato: A preliminary report," Nature, vol. 239, no. 5373, pp. 462-464, 1972.

[34] L. Tangarife Tobón, Cultivo De Células Troncales De Médula Ósea De Rata (Rctmo) En Matrices De Colágeno Tipo I, Para Su Uso En Protocolos De Regeneración De Tejidos, Pontificia Universidad Javeriana, 2014, [cited 2017 Jan 20]; Available from: https://repository.javeriana.edu.co/handle/10554/15457.

[35] A. Ordóñez Vásquez, L. Jaramillo Gómez, M. Ibata, and F. Suárez Obando, "Técnica de Tinta China en células adherentes en cultivo," Nov Publicación Científica en Ciencias Biomédicas, vol. 13, no. 25, pp. 9-17, 2016.

[36] C. T. Brighton and R. M. Hunt, "Early histological and ultrastructural changes in medullary fracture callus," Journal of Bone \& Joint Surgery - American Volume, vol. 76, no. 3, pp. 832-847, 1991.

[37] J. T. Blankemeyer, B. K. Stringer, J. R. Rayburn, J. A. Bantle, and M. Friedman, "Effect of potato glycoalkaloids, .alpha.chaconine and .alpha.-solanine on membrane potential of frog embryos," Journal of Agricultural and Food Chemistry, vol. 40, no. 10, pp. 2022-2025, 1992.

[38] D. Kirk and U. Mittwoch, "Changes in the mitotic cycle induced by $\alpha$-solanine," Human Genetics, vol. 26, no. 2, pp. 105-111, 1975.

[39] S. Fulda, A. M. Gorman, O. Hori, and A. Samali, "Cellular stress responses: cell survival and cell death," International Journal of Cell Biology, vol. 2010, Article ID 214074, 23 pages, 2010.

[40] T. Yu, A. A. Volponi, R. Babb, Z. An, and P. T. Sharpe, "Stem Cells in Tooth Development, Growth, Repair, and Regeneration," Current Topics in Developmental Biology, vol. 115, pp. 187212,2015

[41] Y. B. Ji, S. Y. Gao, C. F. Ji, and X. Zou, "Induction of apoptosis in HepG2 cells by solanine and Bcl-2 protein," Journal of Ethnopharmacology, vol. 115, no. 2, pp. 194-202, 2008.

[42] -F. Tao, L. Hasvold, L. Wang, X. Wang, A. M. Petros, C. H. Park et al., "Discovery of a potent and selective BCL-XL inhibitor with in vivo activity," ACS Medicinal Chemistry Letters, vol. 5, no. 10, pp. 1088-1093, 2014.

[43] M. Hasanain, A. Bhattacharjee, P. Pandey et al., “ $\alpha$-Solanine induces ROS-mediated autophagy through activation of endoplasmic reticulum stress and inhibition of Akt/mTOR pathway," Cell Death \& Disease, vol. 6, no. 8, article 1860, Article ID e1860, 2015.

[44] B. Pan, W. Zhong, Z. Deng et al., "Inhibition of prostate cancer growth by solanine requires the suppression of cell cycle proteins and the activation of ROS/P38 signaling pathway," Cancer Medicine, vol. 5, no. 11, pp. 3214-3222, 2016.

[45] S. Boulon, B. J. Westman, S. Hutten, F.-M. Boisvert, and A. I. Lamond, "The nucleolus under stress," Molecular Cell, vol. 40, no. 2, pp. 216-227, 2010.

[46] S. Langkilde, T. Mandimika, M. Schrøder et al., "A 28-day repeat dose toxicity study of steroidal glycoalkaloids, $\alpha$-solanine and $\alpha$-chaconine in the Syrian Golden hamster," Food and Chemical Toxicology, vol. 47, no. 6, pp. 1099-1108, 2009.

[47] D. D. Carlo, L. Y. Wu, and L. P. Lee, "Dynamic single cell culture array," Lab on a Chip, vol. 6, no. 11, pp. 1445-1449, 2006.

[48] I. E. Zohn, K. V. Anderson, and L. Niswander, "Using genomewide mutagenesis screens to identify the genes required for neural tube closure in the mouse," Birth Defects Research Part A - Clinical and Molecular Teratology, vol. 73, no. 9, pp. 583-590, 2005.

[49] M. J. Harris and D. M. Juriloff, "An update to the list of mouse mutants with neural tube closure defects and advances toward a complete genetic perspective of neural tube closure," Birth Defects Research Part A: Clinical and Molecular Teratology, vol. 88, no. 8, pp. 653-669, 2010.

[50] M. Friedman, "Chemistry and anticarcinogenic mechanisms of glycoalkaloids produced by eggplants, potatoes, and tomatoes," Journal of Agricultural and Food Chemistry, vol. 63, no. 13, pp. 3323-3337, 2015. 


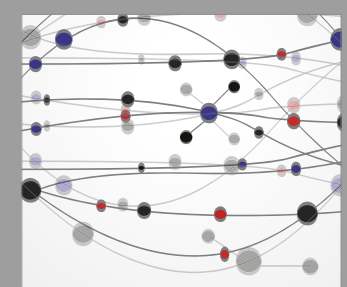

The Scientific World Journal
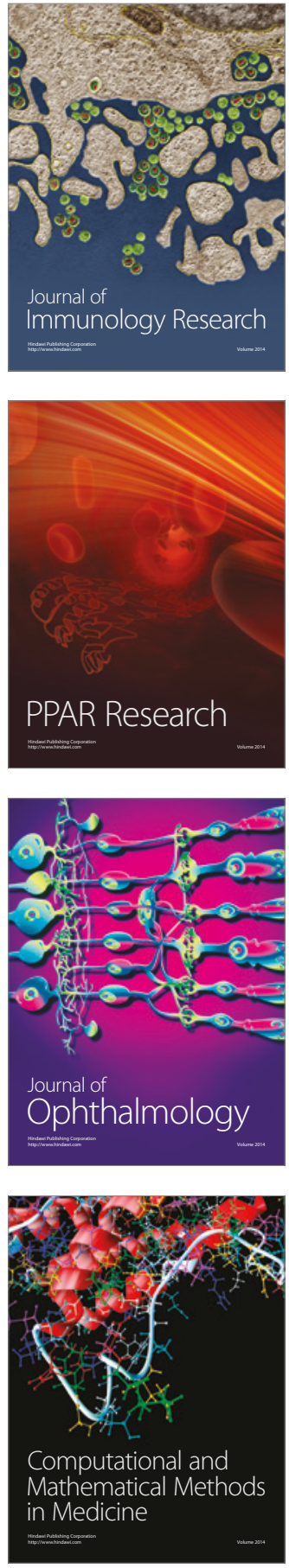

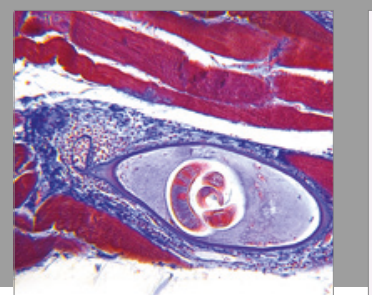

Gastroenterology Research and Practice
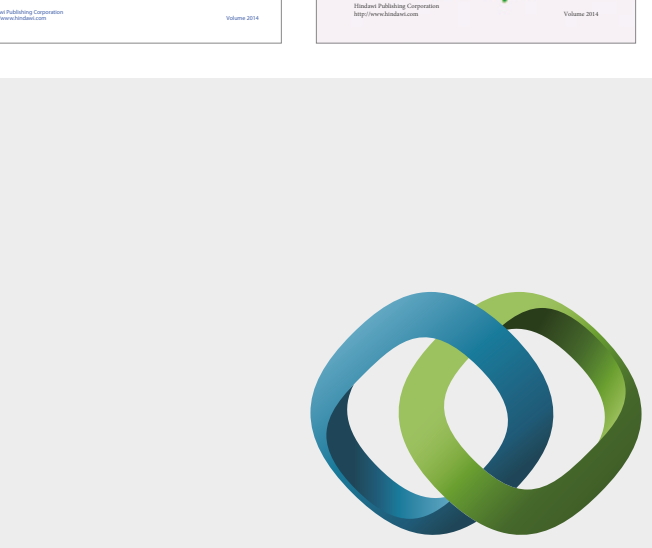

\section{Hindawi}

Submit your manuscripts at

https://www.hindawi.com
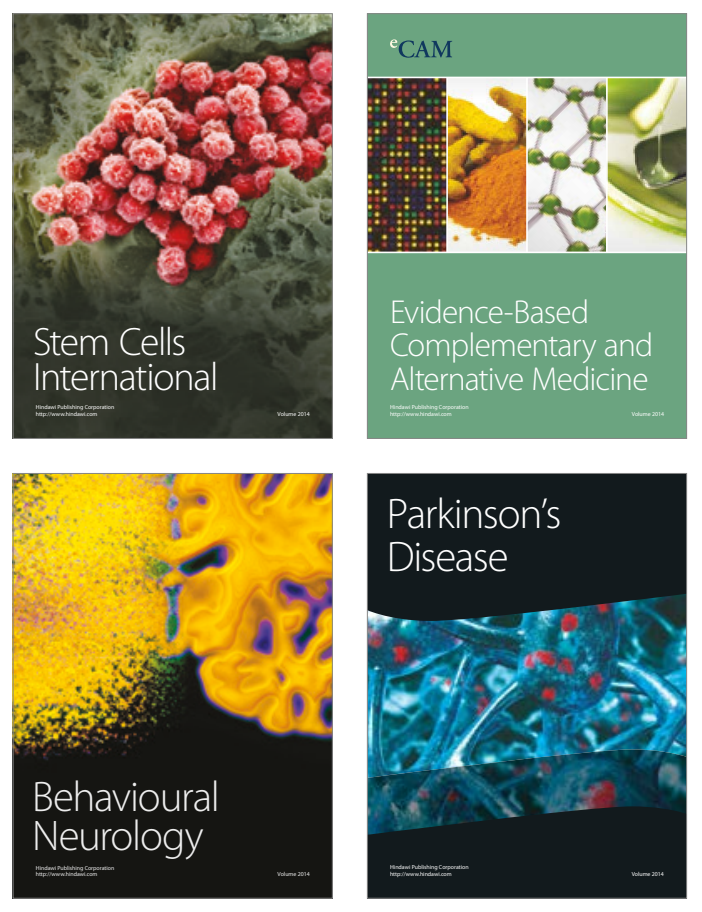
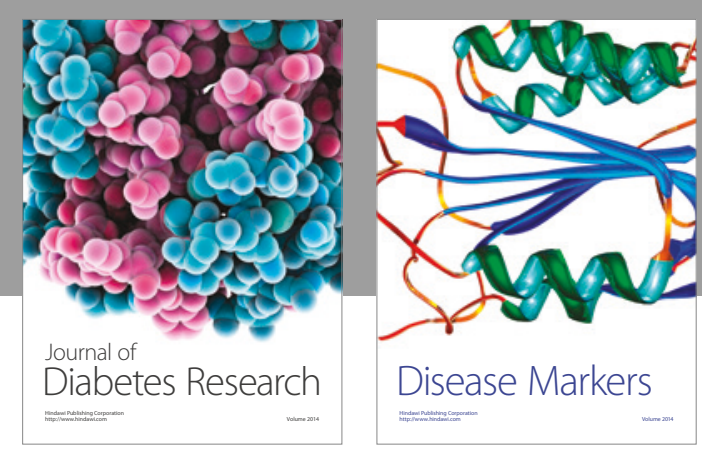

Disease Markers
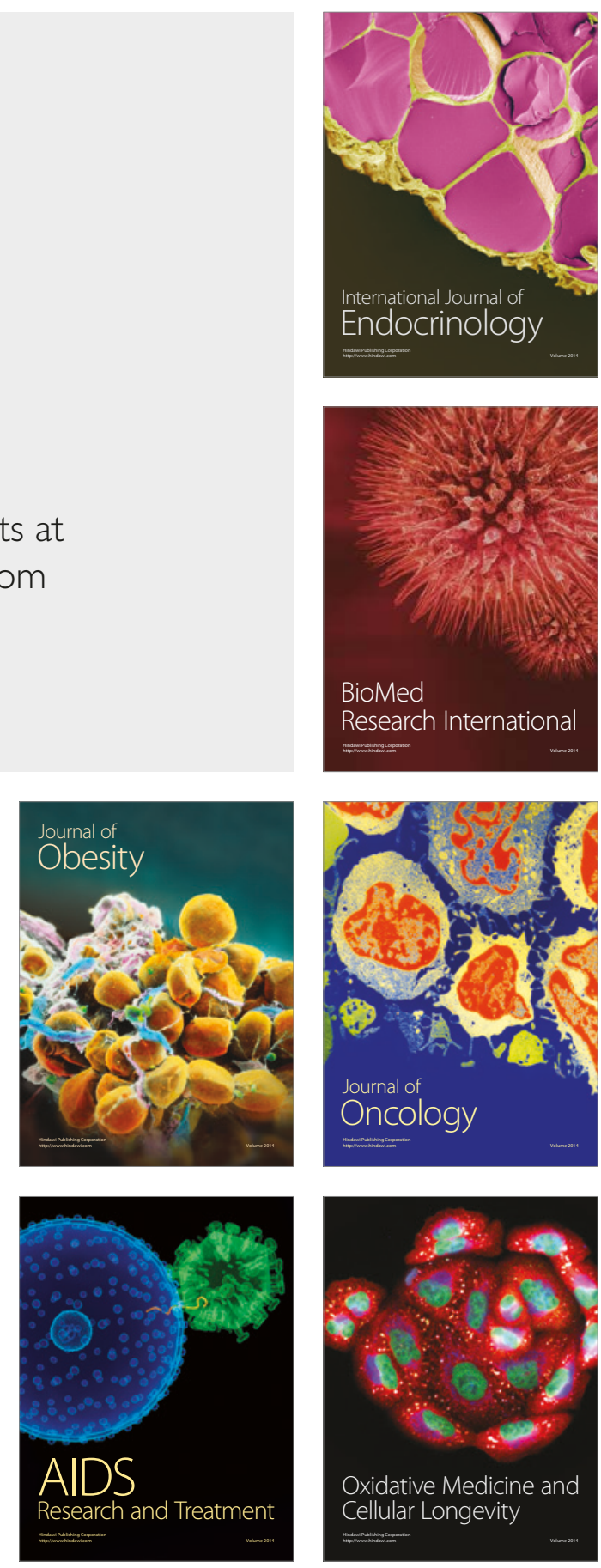